\title{
KETERAMPILAN SOSIAL \\ MELALUI STRATEGI PEMBELAJARAN KOOPERATIF JIGSAW
}

\author{
Sopwan Adi Suprayitno
}

Guru Matematika SMP Negeri 2 Yosowilangun kab. Lumajang

\begin{abstract}
ABSTRAK
Pola pembelajaran tradisional merupakan pola pembelajaran yang mudah diwarisi secara turun temurun dalam praktek pembelajaran di sekolah. Pola ini memang mudah dilaksanakan. Ciri utama pola pembelajaran ini adalah target penyelesaian pada buku ajar/ paket yang utama. Kenyataan ini membuat guru kurang memberdayakan kompetensi siswa, salah satunya adalah keterampilan sosial sebagai motor internal siswa dalam belajar. Keterampilan sosial teruji secara empiris mampu mendorong siswa berprestasi secara akademik dan sosial, oleh karena itu perlu kajian dalam pemilihan strategi pembelajaran yang mampu menumbuhkan keterampilan sosial.
\end{abstract}

Kata Kunci: keterampilan sosial, strategi pembelajaran kooperatif jügsaw.

\section{PENDAHULUAN}

Secara umum pola pembelajaran yang kita alami masih berpusat pada guru (teacher centered), proses pembelajaran ini hanya diarahkan kepada kemampuan anak untuk menghafal informasi. Anak didik dipaksa untuk mengingat dan menimbun berbagai informasi tanpa dituntut untuk memahami memahami informasi yang diingatnya untuk menghubungkannya dengan kehidupan sehariharinya tetapi guru berorientasi pada ketuntasan penyelesaian buku ajar. Kondisi ini sering kita sebut dengan belajar produk (learning by product) dan bukan belajar proses (learning by process). ${ }^{1}$

Pendekatan pembelajaran yang masih berpusat pada guru (teacher centered), guru mendominasi perannya sebagai satu-satunya penyampai informasi melalui ceramah, tanya jawab, menyerahkan tugas, hal ini berakibat peserta didik cenderung untuk menghafal materi pelajaran daripada memahami makna yang dipelajar. siswa pasif ${ }^{2}$. Pembelajaran inilah oleh Lindquist (1997) disebut dengan

\footnotetext{
${ }^{1}$ Sumiati dan Asra. Metode Pembelajaran (Bandung : CV Wancana Prima, 2009), 91

2 Zamroni. 2000. Paradigma Pendidikan Masa Depan. Yogyakarta : Bigraf Publishing:142
} 
pembelajaran tradisional atau Structure Dyadic Methods ${ }^{3}$. Akibat dari pola pembelajaran yang demkian, maka siswa merasa bahwa pembelajaran itu membosankan, hanya menghafal, dan tidak menarik.

Gejala-gejala semacam ini merupakan gejala pembelajaran yang hanya menjejali otak anak dengan berbagai bahan ajar yang harus dihafal; pendidikan tidak diarahkan untuk membangun dan mengembangkan karakter serta potensi yang dimiliki yaitu untuk membangun dan mengembangkan karakter serta potensi yang dimiliki ; dengan kata lain, proses pendidikan tidak diarahkan membentuk manusia yang cerdas, memiliki kemampuan memecahkan masalah hidup, serta tidak diarahkan untuk membentuk manusia yang kreatif dan inovatif. Bergesernya fokus kajian pendidikan dari paradigma behavioristik ke paradigma konstruktivistik telah membawa perubahan besar pada konsep belajar dan mengajar ${ }^{4}$. Dalam pandangan konstruktivistik, mengajar adalah menciptakan kondisi yang mendorong siswa melakukan belajar, sebaliknya peran pebelajar adalah memfasilitasi dan mendorong terjadinya proses belajar, sedangkan proses belajar adalah pengaitan pengetahuan baru pada struktur kognitif yang telah dimiliki siswa ${ }^{5}$.

Pergeseran tersebut, telah menempatkan pembelajaran bergeser dari teacher centered menjadi student centered. Oleh karena itu optimalisasi dan pemberdayaan pembelajar (siswa) dalam kegiatan pembelajaran adalah suatu keharusan. Keterampilan sosial (social skills) merupakan bakat yang dimiliki oleh setiap siswa sebagai makhluk sosial, dan sangat penting bagi siswa dalam pembelajaran. Keterampilan sosial merupakan kompetensi yang melekat pada siswa dan mampu memberikan dorongan pada proses belajar siswa. Keterampilan sosial berkaitan dengan dorongan untuk bekerja sama dengan orang lain dalam menyelesaikan problem belajar ${ }^{6}$. Oleh karena itu setiap siswa dituntut memiliki keterampilan

3 Robert M Mattingly, \& Ronald L. VanSickle, Cooperative Learning and Achievement in Scial Studies : Jigsaw II Social Education: Oct 1991; 55,6; Academic Research Libraty:392

${ }^{4}$ Nyoman Sudana Degeng, 2001. Kumpulan Baban Pembelajaran, Menuju Pribadi Unggul lewat Perbaikan Kualitas Pembelajaran di Perguruan TinggiMalang: UM-LP3: 21

${ }^{5}$ Nyoman Sudana Degeng, 2013, Ilmu Pembelajaran; Klasifikasi Variabel Untuk Pengembangan Teori dan Penelitian. Bandung: Aras Media:4. Pembedaan definisi belajar dan pembelajaran serta hasil belajar sebagai pengaitan struktur baru yang telah dimiliki oleh si belajar telah mempreskripsikan berkembangnya ilmu pembelajaran (instructional science) sebagai ilmu terapan yang mempreskripsikan strategi pembelajaran optimal untuk memudahkan belajar si belajar (siswa).

${ }^{6}$ Punadji Setyosari, 2009, Pembelajaran kolaborasi: Landasan Untuk mengembangkan Keterampilan social, Rasa Saling Menghargai dan Tanggung Jawab. Pidato Pengukuhan 
sosial dalam bekerja sama, sehingga dalam kelompok belajar akan terjadi interaksi yang dinamis untuk saling belajar dan membelajarkan sebagai bagian dari proses sosial manusia.

Dalam problem pembelajaran tersebut, kiranya kita perlu memahami bahwa ada beberapa strategi pembelajaran yang mampu mendorong berkembangnya keterampilan siswa yang salah satunya yaitu pembelajaran kooperatif jugsaw. Hasil kajian empiris, antara lain hasil penelitian Hatim Ali (2011), menunjukkan bahwa ada perbedaan yang signifikan yaitu bahwa pembelajaran kooperatif lebih efektif dalam hal pencapaian hasil belajar yang berupa pengetahuan dan aplikasi kursus menajemen proyek serta berkembangnya keterampilan sosial. ${ }^{7}$ Nayereh, dkk (2011) juga memberikan rekomendasi bahwa pembelajaran kooperatif lebih efektif dalam meningkatkan komunikasi pada mahasiswa keperawatan dibandingkan dengan pembelajaran tradisional. ${ }^{8}$ Zaheer Ahmad dan Nasir Mahmood (2010) memberikan rekomendasi bahwa efek Cooperative learning mampu meningkatkan kerjasama dan peduli terhadap sesama dalam pembelajaran dibandingkan dengan pembelajaran tradisional. ${ }^{9}$ Berkaitan dengan latar belakang hal tersebut diatas, menarik untuk penulis kaji bagaimana keterampilan sosial dalam strategi pembelajaran kooperatif jigsaw dalam kajian konsep.

\section{PEMBAHASAN}

\section{Strategi Pembelajaran Kooperatif Jigsaw}

Pembelajaran kooperatif merupakan strategi pembelajaran kelompokkelompok kecil dengan kemampuan hiterogen. menggunakan berbagai aktifitas belajar untuk meningkatkan pemahaman mereka ${ }^{10}$. Oleh karenanya tujuan dari pembelajaran kooperatif adalah menciptakan situasi dimana keberhasilan individu

Guru Besar Dalam Ilmu Teknologi Pembelajaran Pada Fakultas Ilmu Pendidikan Universitas Negeri Malang, 14 Mei 2009:3

${ }^{7}$ Hatim Ali, 2011. A comparison of cooperative learning and traditional lecture methods in the project management department of a tertiary level institution in Trinidad and Tobago. Caribbean Teaching Scholar , 1 ( 1), 49-64: 61

8 Nayereh Baghcheghi, Hamid Reza Koohestani, Koresh Rezaei, 2011. A Comparison of the Cooperative Learning and Traditional Learning Methods in Theory classes on Nursing Students' Communication Skill With Patients at Clinical Settings. Nurse Education Today, 31 (8), 877 -882:881

9 Zaheer Ahmad, Nasir Mahmood,. (2010). Effects of Cooperative Learning vs. Traditional Instruction on Prospective Teachers' Learning Experience and Achievement. Ankara University, Journal of Faculty of Educational Sciences, 43 (1), 151-164:162

${ }^{10}$ Spencer Kagan, 1994. Cooperative Learning. San Clemente, California: Kagan Publishing: 145

FalASIFA, Vol. 9 Nomor 1 Maret 2018 | 117 
ditentukan dan dipengaruhi oleh keberhasilan kelompoknya ${ }^{11}$. Pembelajaran kooperatif dikembangkan dengan tujuan untuk mencapai tiga hal yaitu hasil belajar akademik, penerimaan terhadap keragaman, dan pengembangan keterampilan sosial ${ }^{12}$.

Ada beberapa prinsip dasar dalam strategi pembelajaran kooperatif, antara lain (1) setiap anggota kelompok (pebelajar) bertanggung jawab atas segalah sesuatu yang dikerjakan dalam kelompoknya, (2) setiap anggota kelompok (pebelajar) harus mengetahui bahwa semua anggota kelompok mempunyai tujuan yang sama, (3) setiap anggota kelompok (pebelajar) harus membagi tugas dan tanggungjwab yang sama diantara anggota kelompoknya, (4) setiap anggota kelompok akan dievaluasi, (5) setiap anggota kelompok (pebelajar) berbagai kepemimpinan dan membutuhkan keterampilan untuk belajar bersama selama proses belajarnya, (6) setiap anggota kelompok (pebelajar) akan diminta untuk mempertanggungjawabkan secara individual materi yang ditangani dalam kelompok kooperatif. ${ }^{13}$ Data empiris menunjukkan bahwa pembelajaran kooperatif mampu meningkatkan prestasi akademik, toleransi dan penerimaan terhadap keanekaragaman, pengembangan keterampilan sosial, menumbuhkan sikap menerima kekurangan diri dan orang lain, serta mampu meningkatkan harga diri. Selain itu pembelajaran kooperatif juga dapat merealisasikan kebutuhan pebelajar (siswa) dalam belajar berfikir, memecahkan masalah, dan mengintegrasikan pengetahuan dan keterampilan sosial. ${ }^{14}$

Pembelajaran kooperatif teknik jugsaw merupakan salah satu tipe pembelajaran kooperatif yang mendorong siswa aktif dan saling membantu dalam menguasai materi pelajaran untuk mencapai prestasi yang maksimal. Pembelajaran kooperatif jugsaw telah dikembangkan dan diuji cobakan oleh Elliot Aronson dan kemudian diadaptasi oleh Slavin.

Model pembelajaran Jigsaw merupakan salah satu bentuk pembelajaran yang dinamis dan mengutamakan siswa untuk melakukan kegiatan belajar dengan bekerjasama dalam kelompok. Jigsaw adalah salah satu dari bentuk metode

${ }^{11}$ Robert E Slavin, 1994. Using Student Team Learning, Baltomoro: Johnshopkins University:25

12 Richard Arends, 1997. Cooperative Learning Classroom Instructions and Management. New York:Me Graw- Hill Companies. Inc:17

${ }_{13}$ Muslimin Ibrahim., Fida Rachmadiarti, Muhamad Nur, \& Ismono, 2001. Pembelajaran Kooperatif. Surabaya. UNESA University Press:9

${ }^{14}$ Renante P. Manlunas, 2010. ICT and Cooperative Learning: Reinventingthe Classroom Prefesional Education Division. (online), (www.slideshare.net/.../ict-andcooperaive-learning reinventing-the classroom), diakses 16 Pebruari 2014. 
kooperatif yang paling fleksibel. Jigsaw yang berarti gergaji atau puzzle yaitu gambar yang di potong-potong secara acak yang harus disusun ulang menjadi seperti bentuk asli sebelum di potong. ${ }^{15}$

Ciri khas pembelajaran kooperatif bentuk jigsaw adalah siswa ditugaskan dalam kelompok yang terdiri dari 4-6 orang anggota, untuk bekerja pada materi akademik yang telah dipecah-pecah ke dalam bagian demi bagian ${ }^{16}$ Jigsaw di desain untuk meningkatkan rasa tanggungjawab siswa secara mandiri terhadap pembelajarannya sendiri dan juga pembelajaran orang lain. Selain itu, siswa di tuntut untuk salingtergantungan secara positif atau saling ketergantungan berbalas terhadap sesama teman dalam kelompok. ${ }^{17}$ Hal ini menjadi lebih penting karena telah menekankan peran kerjasama antar teman di dalam pembelajaran. Siswa tidak hanya mempelajari materi yang diberikan, tetapi juga harus mengajarkan materi itu kepada anggota kelompoknya. ${ }^{18} \mathrm{Hal}$ ini seperti yang dijelaskan dalam gambar 2.1. yang mengilustrasikan hubungan antara tim asal dan ahli dalam pembelajaran kooperatif jugsaw di bawah ini .

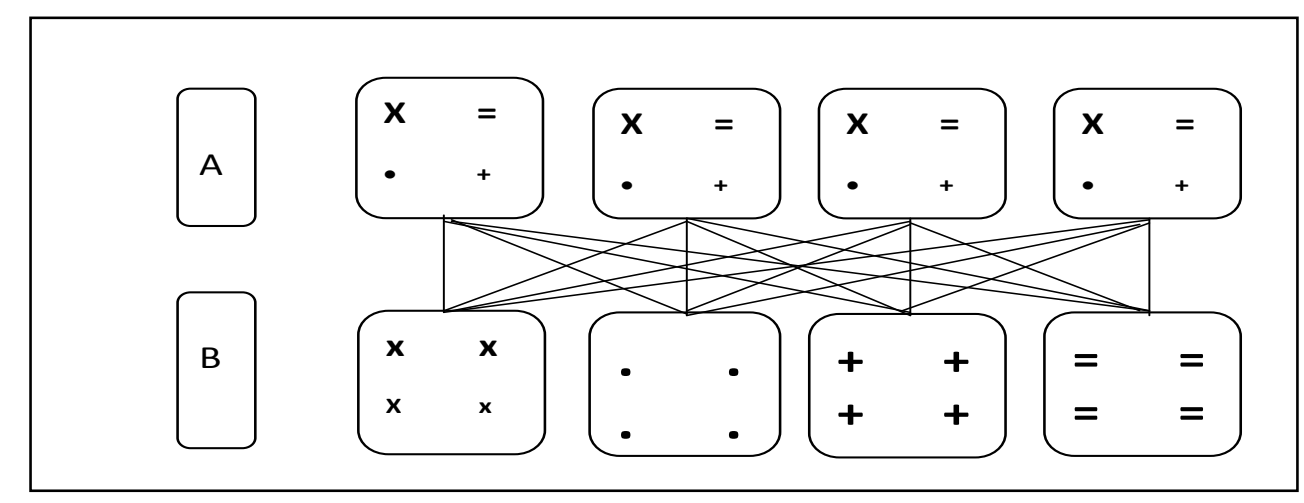

Keterangan:

$\mathrm{A}=$ Posisi kelompok asal (induk) : siswa secara bersama dalam kelompok

${ }^{15}$ Herawati Susilo, 2007, Pengembangan Kemampuan Berfikir dan Assessment Dalam Strategi Kooperatif, Makalah disajikan dalam Pelatihan Pengembangan Assessment Autentik dan Kemampuan Berfikir secara implementasi dalam pembelajaran kooperatif. Malang: Universitas Muhammadiyah Malang:3

${ }^{16}$ Robert E. Slavin, 2000. Educational Psychology: Theory and Practice. Sixth Edition. Boston: Allyn and Bacon: 123

${ }^{17}$ Elizabeth G Cohen,.1998. Making Cooperative Learning Equitable. Journal of Educational Leadership, 56 (5) , 18-21:19

18 Tanwey Gerson Ratumanan, 2004, Belajar dan Pembelajaran, Edisi ke-2. Surabaya: Unesa University Press: 71

${ }^{19}$ Robert E Slavin, 2008. Cooperative learning: Teori, Riset dan Praktik. Bandung: Nusamedia:121 
Sopwan Adi Suprayitno

mendapatkan tugas secara bersama- bersama.

B = Posisi kelompok ahli (khusus): siswa bergabung dalam kelompokkelompok ahli, mereka memiliki keahlian dalam tugas yang sama.

Dalam pembelajaran kooperatif jügsaw, pelaksanaan strategi pembelajaran diatur dan dikembangkan oleh pembelajar dengan memperhatikan tata cara pelaksanaannya. Secara sederhana, sintaks strategi pembelajaran kooperatif teknik jugsaw tersebut dapat dijelaskan dalam bagan sebagai berikut:

\begin{tabular}{|c|c|c|}
\hline NO. & TAHAP & URAIAN KEGIATAN DAN SISWA \\
\hline 1. & $\begin{array}{l}\text { I. Tahap } \\
\text { Penda } \\
\text { huluan }\end{array}$ & $\begin{array}{l}\text { 1. Guru memberikan review, apersepsi, motivasi kepada } \\
\text { seluruh siswa. } \\
\text { 2. Menjelaskan pada siswa tentang model pembelajaran } \\
\text { yang dipakai dan menjelaskan bahwa setiap siswa } \\
\text { dituntut bertanggungjawab pada bagian materi yang } \\
\text { dipelajari. } \\
\text { 3. Pembentukan kelompok dengan jumlah anggota setiap } \\
\text { kelompok terdiri dari } 4 \text {-5 siswa dengan kemampuan } \\
\text { yang hiterogen } \\
\text { 4. Pembagian materi / soal pada masing-masing anggota } \\
\text { kelompok }\end{array}$ \\
\hline 2. & $\begin{array}{l}\text { Tahap } \\
\text { Penguasa } \\
\text { an }\end{array}$ & $\begin{array}{l}\text { 1. Siswa mempelajari materi yang menjadi bagiannya, } \\
\text { selanjutnya bergabung dalam kelompok dalam } \\
\text { kelompok ahli dengan tugas yang sama dan berusaha } \\
\text { menguasai materi sesuai dengan soal yang diterima, } \\
\text { dengan soal/ materi yang sama. } \\
\text { 2. Guru memberikan bantuan sepenuhnya kepada siswa } \\
\text { untuk menguasai materi pelajaran sesuai dengan } \\
\text { kelompoknya. }\end{array}$ \\
\hline 3. & $\begin{array}{l}\text { Tahap } \\
\text { Penularan }\end{array}$ & $\begin{array}{l}\text { 1. Setiap siswa kembali ke kelompok asalnya. } \\
\text { 2. Tiap siswa dalam kelompok saling menularkan dan } \\
\text { menerima materi dari siswa lain, dengan cara bergantian } \\
\text { memberikan penjelasan terhadap materi yang } \\
\text { dipalajarinya. } \\
\text { 3. Diharapkan terjadi tanya jawab atau diskusi antar siswa } \\
\text { dalam kelompok asal. } \\
\text { 4. Dari hasil saling memberikan penjelasan atau diskusi } \\
\text { dalam kelompok diharapkan siswa mampu mengerjakan }\end{array}$ \\
\hline
\end{tabular}

120 | ҒaLASIFA, Vol. 9 Nomor 1 Maret 2018 
Memberdayakan Keterampilan Sosial...

\begin{tabular}{|l|l|l|l|}
\hline & & \multicolumn{3}{|c|}{ atau menjawab soal yang diberikan oleh guru } \\
\hline 4. & $\begin{array}{l}\text { Tahap } \\
\text { Penutup }\end{array}$ & $\begin{array}{l}\text { 1. Guru bersama siswa membahas soal yang telah } \\
\text { dikerjakan. } \\
\text { 2. Kuis/ evaluasi dan penskoran hasil jawaban siswa }\end{array}$ \\
\hline
\end{tabular}

Tabel 1. Sintaks Strategi Pembelajaran Kooperatif Jigsaw ${ }^{20}$

\section{Keterampilan sosial.}

Liber dan Levinson sebagaimana dikutip Gwendolyn Cartledge dkk, menjelaskan bahwa keterampilan sosial adalah kemampuan yang kompleks dalam memperlihatkan perilaku-perilaku secara positif atau negatif, dan tidak menghasilkan perilaku yang sekiranya tidak menimbulkan hukuman atau penindasan dari orang lain). ${ }^{21}$ Keterampilan sosial merupakan kemampuan individu untuk berkomunikasi efektif dengan orang lain baik secara verbal maupun nonverbal sesuai dengan situasi dan kondisi yang ada pada saat itu, di mana keterampilan ini merupakan perilaku yang dipelajari. Hargie, Saunders, \& Dickson sebagaimana dikutip Gimpel \& Merrill lebih jauh mengungkapkan bahwa remaja dengan keterampilan sosial yang dimiliki akan mampu mengungkapkan perasaan baik positif maupun negatif dalam hubungan interpersonal, tanpa harus melukai orang lain. ${ }^{22}$

Keterampilan sosial merupakan kemampuan untuk berinteraksi dengan orang lain dalam suatu kontak sosial tertentu dengan cara khusus yang secara sosial bisa diterima atau dihargai sekaligus bermanfaat secara pribadi, sekaligus menguntungkan bagi orang lain. Oleh karena itu keterampilan sosial merupakan kemampuan bekerja sama dalam mengahadapi masalah-masalah sosial dalam segalah aspek kehidupan yang dihadapi dalam kehidupan nyata di masyarakat.

Keterampilan sosial membawa orang untuk lebih berani berbicara, mengungkapkan setiap perasaan atau permasalahan yang dihadapi dan sekaligus menemukan penyelesaian yang adaptif, sehingga mereka tidak mencari pelarian ke hal-hal lain yang justru dapat merugikan diri sendiri maupun orang lain. Libet dan Lewinsohn (dalam Cartledge dan Milburn, 1995) mengemukakan keterampilan sosial sebagai kemampuan yang kompleks untuk menunjukkan perilaku yang baik dinilai secara positif atau negative oleh lingkungan, dan jika perilaku itu tidak baik

\footnotetext{
${ }^{20}$ Robert E. Slavin, 2005. Cooperative Learning: ...: 130

${ }^{21}$ Gwendolyn Carledge, and Joanne Fellows Milburn,. 1992. Teaching Social Skill To Children (Second Edition). New York: Pergamon Press: 176

${ }^{22}$ Kenneth W Merrell, \& Gretchen A. Gimpel, 1998. Socail Skills of Children and Adolescents. Conceptualization, Assessment, Treatment. London: Lawrence Erlbaum Associates Publishes:103
}

FALASIFA, Vol. 9 Nomor 1 Maret 2018 | 121 
akan diberikan punishment oleh lingkungan. ${ }^{23}$ Kelly sebagaimana dikutip Gimpel \& Merrel mendefinisikan keterampilan sosial sebagai perilaku-perilaku yang dipelajari, yang digunakan oleh individu pada situasi-situasi interpersonal dalam lingkungan. ${ }^{24}$ Keterampilan sosial, baik secara langsung maupun tidak membantu remaja untuk dapat menyesuaikan diri dengan standar harapan masyarakat dalam norma-norma yang berlaku di sekelilingnya ${ }^{25}$.

Ada beberapa indikator dari suatu keterampilan sosial (social skills) yang dimiliki pembelajar yaitu: 1) perilaku terhadap lingkungan (Environmental Behavior) yang meliputi: menjaga kelestarian lingkungan sekolah, menerima keadaan diluar perkiraan atau kebiasaan sehari-hari, berinteraksi (bergaul) dengan orang-orang yang ada di lingkungan sekolah (guru, pegawai, dll), 2) perilaku antar pribadi (interpersonal behavior) yang meliputi: menerima otoritas, mengatasi konflik dengan teman sebaya, memulai percakapan dengan orang lain, bersikap positif terhadap teman, menjaga privasi orang lain, senang membantu orang lain, 3) perilaku pribadi (self-related behavior) yang meliputi: dapat mengekspresikan perasaan, bersikap positif terhadap diri sendiri, memiliki dan menjaga sikap etis, menyadari dan menerima konsekuensi atas perbuatan sendiri, menjaga dan merawat kondisi tubuh, 4) perilaku dalam tugas-tugas akademis (task-related behavior) yang meliputi: memperhatikan selama pelajaran berlangsung, bertanya atau menjawab pertanyaan yang diberikan guru dan teman dalam pembelajaran, memenuhi tugas-tugas di kelas. ${ }^{26}$ Sedangkan Carolyn Kessler (1992), mengindikasikan ada 2 indikator keterampilan sosial yang berkembang dalam proses pembelajaran (1) mencari informasi (obtaining information) yang meliputi: bertanya untuk informasi, meminta klarifikasi, meminta penjelasan, meminta konfirmasi, meminta pengulangan, mengungkapkan ketidakpercayaan, memverifikasi komunikasi, interupsi, kembali ke topik, menebak. (2) Memberi Informasi (Giving Information) yang meliputi: menjelaskan, mengulang, menggambarkan, menyimpulkan, eksepsi, mempresentasikan pendapat, memberikan keyakinan, menambah pikiran/ pendapat, memberikan alasan, memberikan pertimbangan, berpikir kedepan, meringkas, menguji pemahaman, memverifikasi pemahaman. ${ }^{27}$

\footnotetext{
${ }^{23}$ Gwendolyn Carledge, and Joanne Fellows Milburn,. 1992. Teaching Social Skill $\ldots 122$

${ }^{24}$ Kenneth W Merrell, \& Gretchen A. Gimpel, 1998. Socail Skills of....140

${ }^{25}$ Ibid, 148.

${ }^{26}$ Ibid.

${ }^{27}$ Carolyn Kessler, 1992, Cooperative Language Learning, New Jersey, PrenticeHall.Inc:78
} 
Pembelajar yang berada dalam fase perkembangan masa remaja memiliki ketrampilan sosial (social skills) untuk dapat menyesuaikan diri dengan kehidupan sehari-hari. Keterampilan keterampilan sosial tersebut meliputi kemampuan berkomunikasi, menjalin hubungan dengan orang lain, menghargai diri sendiri dan orang lain, mendengarkan pendapat atau keluhan dari orang lain, memberi atau menerima feedback, memberi atau menerima kritik, bertindak sesuai norma dan aturan yang berlaku, dsb (Mu'tadin, 2006). Oleh karenanya apabila keterampilan sosial dapat berkembang dan dikuasai oleh pembelajar yang berada pada fase tersebut maka ia dimungkinkan mampu menyesuaikan diri dengan lingkungan sosialnya.

Isjoni (2009), menyampaikan bahwa pada era globalisasi yang ditandai dengan persaingan kerjasama di segala aspek kehidupan masyarakat, maka siswa harus memiliki keterampilan sosial dan sikap posiitif sosial sebagai anggota masyarakat lokal ataupun global yang demokratis dapat dikembangkan lebih lanjut melalui strategi pembelajaran kooperatif. ${ }^{28}$

\section{Kajian konseptual: Keterampilan Sosial dalam Pembelajaran kooperatif Jigsaw.}

Ada lima elemen dasar agar dalam suatu kelompok terjadi pembelajaran kooperatif. (1) saling ketergantungan positif, mereka harus percaya dihubungkan dengan cara yang lain dan memastikan bahwa mereka semua berhasil bersamasama. Masing-masing pembelajar mungkin mempunyai peran berbeda, tetapi itu harus krusial/penting bagi proses kelompok. Di dalam kelompok ini masingmasing pembelajar saling berhubungan yang secara psikologis, mereka sadar akan kondisi dan posisi masing-masing, dan mereka merasa menjadi bagian dari anggota kelompok. (2) tatap muka, bahwa hasil belajar yang terbaik dapat diperoleh dengan adanya kemunikasi verbal antar pembelajar yang didukung oleh sikap saling ketergantungan positif. pembelajar saling berhadapan (bertatap muka) dan saling membantu dalam mencapai tujuan belajar. (3) tanggung jawab Individu, bahwa dalam suatu kelompok pembelajar dapat menyumbang, mendukung, dan membantu satu dengan lainnya. Setiap pembelajar dituntut untuk menguasai materi yang dijadikan pokok pembahasan. Dengan demikian setiap anggota kelompok dituntut bertangungjawab untuk mempelajari materi dan bertanggungjawab terhadap kesuksesan kelompok dalam memperoleh hasil

28 Isjoni. (2009). Pembelajaran Kooperatif Meningkatkan Kecerdasan Kommnikasi Antar Peserta Didik. Yogyakarta: Pustaka Belajar:25

FalASIfA, Vol. 9 Nomor 1 Maret 2018 | 123 
belajar. (4) keterampilan kelompok dan interpersonal. Keterampilan sosial ini sangat penting bagi pembelajar dalam pembelajaran. Setiap pembelajar dituntut memiliki keterampilan sosial dalam bekerja sama, sehingga dalam kelompok belajar akan terbangun interaksi yang dinamis untuk saling belajar dan membelajarkan sebagai bagian dari proses pembelajaran kooperatif. (5) keefektifan proses kelompok, pembelajar memproses kefektifan kelompok belajarnya dengan cara memberikan penjelasan tindakan mana yang dapat memberikan sumbangan belajar dan mana yang tidak mendukung belajar untuk dilakukan tindak lanjut atau dilakukan perubahan.$^{29}$.

Dalam pembelajaran kooperatif jugsaw keterampilan sosial terbangun melalui proses interaksi antar siswa dalam kelompok belajar. Siswa dimungkinkan sekali antar pribadi maupun kelompok, baik pada kelompok induk (asal) maupun kelompok ahli melakukan interaksi. Maka melalui interaksi dalam pembelajaran kooperatif inilah berkembang keterampilan sosial yang intensif yang antara lain berwujud: (1) menyimak dengan penuh perhatian, (2) membaca petunjukpetunjuk nonverbal, menyelesaikan ketidaksepakatan (secara diplomastis), (3) mencurahkan pikiran ke dalam kata-kata, (4) Memahami sudut pandang orang lain, (5) membuat pernyataan mendukung, (6) Memberikan pujian tulus. ${ }^{30}$

Dalam pembelajaran kooperatif jigsaw, Seiring dengan perkembangan fungsi bahasa dalam interaksi dalam pembelajaran, berkembang bahasa keterampilan sosial (social skills) antara lain (1) mencari informasi (obtaining information) yang meliputi: bertanya untuk informasi, meminta klarifikasi, meminta penjelasan, meminta konfirmasi, meminta pengulangan, mengungkapkan ketidakpercayaan, memverifikasi komunikasi, interupsi, kembali ke topik, menebak. (2) Memberi Informasi (Giving Information) yang meliputi: menjelaskan, mengulang, menggambarkan, menyimpulkan, eksepsi, mempresentasikan pendapat, memberikan keyakinan, menambah pikiran/ pendapat, memberikan alasan, memberikan pertimbangan, berpikir kedepan, meringkas, menguji pemahaman, memverifikasi pemahaman. ${ }^{31}$

Pembelajaran kooperatif jigsaw yang menempat komunikasi dan kerja sama dalam kelompok baik pada kelompok asal maupun kelompok ahli, telah

${ }^{29}$ Roger T .Johnson, dan Johnson W. David, 2006. What is Cooperative Learning. Minneapolis, Minneasota: The Cooperative Learning Center at The University of Minneasota: 210

${ }^{30}$ Paul Eggen, Don Kauchak, 2012, Strategie And Models For Teachers: Teaching Content And Skills, Boston, Sixch Edition, Person education. Inc.:24

${ }^{31}$ Carolyn Kessler, 1992, Cooperative Language Learning, New Jersey, PrenticeHall.Inc:89 
memperkuat saling ketergantungan positif antar pembelajar dalam kelompok. Oleh karena itu pembelajaran kooperatif jigsaw mendorong berkembangnya sosal yang diindikatorkan dengan berkembangnya : 1) perilaku terhadap lingkungan (Environmental Behavior) yang meliputi: menjaga kelestarian lingkungan sekolah, menerima keadaan diluar perkiraan atau kebiasaan sehari-hari, berinteraksi (bergaul) dengan orang-orang yang ada di lingkungan sekolah (guru, pegawai, dll), 2) perilaku antar pribadi (interpersonal behavior) yang meliputi: menerima otoritas, mengatasi konflik dengan teman sebaya, memulai percakapan dengan orang lain, bersikap positif terhadap teman, menjaga privasi orang lain, senang membantu orang lain, 3) perilaku pribadi (self-related behavior) yang meliputi: dapat mengekspresikan perasaan, bersikap positif terhadap diri sendiri, memiliki dan menjaga sikap etis, menyadari dan menerima konsekuensi atas perbuatan sendiri, menjaga dan merawat kondisi tubuh, 4) perilaku dalam tugastugas akademis (task-related behavior) yang meliputi: memperhatikan selama pelajaran berlangsung, bertanya atau menjawab pertanyaan yang diberikan guru dan teman dalam pembelajaran, memenuhi tugas-tugas di kelas. ${ }^{32}$

Oleh karena itulah Sebagai bakat bawaan manusia sejak lahir, keterampilan sosial (Social skills) dalam proses pembelajaran mendorong anak berperilaku aktif dalam pembelajaran, kemudian perilaku ini akan berdampak kemampuan perolehan kompetensi belajar. Seiring dengan berkembangnya keterampilan sosial pembelajar, maka keterampilan komunikasi telah berkembang secara intensif. Perspektif motivational pada pembelajaran kooperatif terutama memfokuskan pada penghargaan atau struktur tujuan. ${ }^{33}$ Struktur tujuan kooperatif menciptakan sebuah situasi dimana satu-satunya cara anggota kelompok bisa meraih tujuan pribadi adalah jika kelompok mereka bisa sukses. Oleh karena itu untuk mencapai tujuan personal mereka, maka mereka harus saling membantu, dan bekerja maksimal. Dalam pembelajaran kooperatif jigsaw siswa bekerja sama, selalu hadir di kelas, dan membantu yang lainnya belajar akan dipuji dan didukung oleh teman

${ }^{32}$ Kenneth W Merrell, \& Gretchen A. Gimpel,. 1998. Social skills of children and adolescents: Conceptualization, assessment, treatment. New York: Mahwah, N.J:122

${ }^{33}$ Robert E. Slavin, 2008. Cooperative learning: Teori, Riset dan Praktik. Bandung: Nusamedia:155. Slavin menyebutnya dengan ketergantungan positif, sedangkan Cagan memberikan istilah dengan ketergantungan berbalas. Ketergantungan ini telah menjadikan tiap siswa memiliki tanggungjawab untuk menguasai permasalahan secara maksimal, melalui kegiatan kooperatif. Kemudian tiap anggota juga memiliki kewajiban untuk mengajarkan kembali pada anggota kelompok yang lain. Begitu seterusnya sehingga setiap individu sangat bertanggungjawab pada keberhasilan kelompoknya. Tidak ada keberhasilan individu yang diagungkan kecuali keberhasilan bersama.

FALASIFA, Vol. 9 Nomor 1 Maret 2018 | 125 
satu timnya. ${ }^{34}$ Hal ini sesuai dengan peran dan kedudukan anggota kelompok dalam tugasnya sebagai kelompok ahli yang menjadi wakil kelompok asal untuk mencari dan menyampaikan kembali bahan materi yang dikaji dalam jügsaw.

\section{KESIMPULAN}

Berdasarkan kajian konsep tentang keterampilan sosial dalam pembelajaran kooperatif jugsaw dapat di simpulkan sebagai berikut:

1. Pembelajaran kooperatif telah mendorong terjadinya; saling ketergantungan positif, tatap muka, tanggung jawab individu, keterampilan kelompok dan interpersonal dan keefektifan proses kelompok telah mendorong berkembangnya dasar-dasar bagi berkembangnya keterampilan sosial.

2. Pembelajaran kooperatif jügsaw, sebagai salah satu pembelajaran kooperatif telah mengintensifkan kooperatif antar pembelajar dalam kelompok baik pada kelompok asal maupun pada kelompok ahli.

3. Keterampilan sosial yang berkembang pada strategi pembelajaran kooperati jüssaw antara lain; secara khusus mencari informasi (obtaining information) yang meliputi: bertanya untuk informasi, meminta klarifikasi, meminta penjelasan, meminta konfirmasi, meminta pengulangan, mengungkapkan ketidakpercayaan, memverifikasi komunikasi, interupsi, kembali ke topik, menebak. (2) Memberi Informasi (Giving Information) yang meliputi: menjelaskan, mengulang, menggambarkan, menyimpulkan, eksepsi, mempresentasikan pendapat, memberikan keyakinan, menambah pikiran/ pendapat, memberikan alasan, memberikan pertimbangan, berpikir kedepan, meringkas, menguji pemahaman, memverifikasi pemahaman. Dalam perkembangan keterampilan sosial berwujud 1) perilaku terhadap lingkungan (Environmental Behavior) yang meliputi; 2) perilaku antar pribadi (interpersonal behavior); 3) perilaku pribadi (self-related behavior); dan 4) perilaku dalam tugas-tugas akademis (task-related behavior).

4. Dalam pembelajaran, untuk mengoptimalkan hasil belajar siswa, perlulah seorang pembelajar (guru, dosen) memahmi makna belajar, mengajar, dan hasil belajar sehingga bisa memilih model, strategi dan metode pembelajaran yang mampu mendorong berkembangnya keterampilan sosial dalam belajar. Karena keterampilan sosial yang ada pada si belajar (pebelajar) merupakan motor bagi berkembangnya perolehan hasil belajar yang optimal.

\footnotetext{
${ }^{34}$ Rusman. 2008. Pembelajaran Jigsaw. Jakarta: Bumi Aksara:205
} 


\section{DAFTAR PUSTAKA}

Ahmad, Z., \& Mahmood, N. 2010. Effects of Cooperative Learning vs. Traditional Instruction on Prospective Teachers' Learning Experience and Achievement. Ankara University, Journal of Faculty of Educational Sciences, 43 (1), 151-164.

Ali, H. 2011. A comparison of cooperative learning and traditional lecture methods in the project management department of a tertiary level institution in Trinidad and Tobago. Caribbean Teaching Scholar, 1 ( 1), 49-64.

Arends, R. 1997. Cooperative Learning Classroom Instructions and Management. New York:Me Graw- Hill Companies. Inc.

Baghcheghi, N., Khoohestani, H. R., \& Rezaei, K. 2011. A Comparison of the Cooperative Learning and Traditional Learning Methods in Theory classes on Nursing Students' Communication Skill With Patients at Clinical Settings. Nurse Education Today, 31 (8), 877 -882.

Carledge, Gwendolyn, and Milburn, Joanne Fellows. 1992. Teaching Social Skill To Children (Second Edition). New York: Pergamon Press.

Cohen, E. G. 1998. Making cooperative learning equitable. Educational Leadership, 56, 18-22

Degeng, I.N. 2001. Kumpulan Bahan Pembelajaran, Menuju Pribadi Unggul lewat Perbaikan Kualitas Pembelajaran di Perguruan TinggiMalang: UM-LP3.

Degeng, N. S. 2013. Ilmu Pembelajaran; Klasifikasi Variabel Untuk Pengembangan Teori dan Penelitian. Bandung: Aras Media.

Eggen, Paul, Kauchak, Don, 2012, Strategie And Models For Teachers: Teaching Content And Skills, Sixch Edition, Person education. Inc., Boston

Ibrahim, M., Rahmadiarti,F., Nur, M., \& Ismono, 2001. Pembelajaran Kooperatif. Surabaya. UNESA University Press.

Isjoni. (2009). Pembelajaran Kooperatif Meningkatkan Kecerdasan Komunikasi Antar Peserta Didik. Yogyakarta: Pustaka Belajar

Johnson, Roger T. dan David W. Johnson, 2006. What is Cooperative Learning. Minneapolis, Minneasota: The Cooperative Learning Center at The University of Minneasota.

Kagan, S., 1994. Cooperative Learning. San Clemente, California: Kagan Publishing

Kessler, Carolyn, 1992, Cooperative Language Learning, New Jersey, PrenticeHall.Inc. 
Sopwan Adi Suprayitno

Manlunas, R.P. 2010. ICT and Cooperative Learning: Reinventingthe Classroom Prefesional Education Division. (online), (www.slideshare.net/.../ict-andcooperaive-learning reinventing-the classroom), diakses 16 Pebruari 20

Mattingly, Robert M, \& VanSickle, Ronald L. Cooperative Leaming and Achievement in Scial Studies : Jigsaw II Social Education: Oct 1991; 55,6; Academic Research Libraty pg. 392.

Merrell, K. W., \& Gimpel, G. A. (1998). Social skills of children and adolescents: Conceptualization, assessment, treatment. New York: Mahwah, N.J.

Ratumanan, T.G., 2004, Belajar dan Pembelajaran, Edisi ke-2.Surabaya: Unesa University Press.

Rusman. 2008. Pembelajaran Jigsaw. Jakarta: Bumi Aksara

Setyosari, P, 2009, Pembelajaran kolaborasi: Landasan Untuk mengembangkan Keterampilan social, Rasa Saling Menghargai dan Tanggung Jawab. Pidato Pengukuhan Guru Besar Dalam Ilmu Teknologi Pembelajaran Pada Fakultas Ilmu Pendidikan Universitas Negeri Malang, 14 Mei 2009.

Slavin, R.E. 2005. Cooperative Learning: Teori, Riset, dan Praktik. (Terjamah olehNurulita). Bandung: Nusa Media

Slavin, R.E. 2000. Educational Psychology: Theory and Practice. Sixth Edition. Boston: Allyn and Bacon.

Slavin, Robert E. 1994. Using Student Team Learning, Baltomoro: Johnshopkins University.

Slavin, Robert. 2008. Cooperative learning: Teori, Riset dan Praktik. Bandung: Nusamedia

Sumiati dan Asra, 2009, Metode Pembelajaran, Bandung : CV Wancana Prima

Susilo, H. 2007, Pengembangan Kemampuan Berfikir dan Assessment Dalam Strategi Kooperatif, Makalah disajikan dalam Pelatihan Pengembangan Assessment Autentik dan Kemampuan Berfikir sera implementasi dalam pembelajaran kooperatif. Malang: Universitas Muhammadiyah Malang.

Zamroni. 2000. Paradigma Pendidikan Masa Depan. Yogyakarta : Bigraf pub. 